Cliff Goddard* and Kerry Mullan

\title{
Explicating verbs for "laughing with other people" in French and English (and why it matters for humour studies)
}

https://doi.org/10.1515/humor-2017-0114

\begin{abstract}
This study undertakes a contrastive lexical-semantic analysis of a set of related verbs in English and French (English to joke and to kid, French rigoler and plaisanter), using the Natural Semantic Metalanguage (NSM) approach to semantic analysis. We show that the semantic and conceptual differences between French and English are greater than commonly assumed. These differences, we argue, have significant implications for humor studies: first, they shed light on different cultural orientations towards "laughter talk" in Anglo and French linguacultures; second; they highlight the danger of conceptual Anglocentrism in relying on English-specific words as a theoretical vocabulary for humor studies.
\end{abstract}

Keywords: French, humor, joking, laughter talk, lexical semantics, Natural Semantic Metalanguage (NSM)

\section{Introduction}

First of all, it is important to explain our choice of title; in particular, the phrase "verbs for "laughing with other people." Why not use a shorter and more familiar expression, such as "humor-related verbs" or "verbs for joking"? The reason is simply that neither of these expressions would be cross-translatable into French. Although it is generally accepted that humor is a universal human behavior (cf. Martin 2006), how individuals understand and use humor differs, as illustrated by the Humor Styles Questionnaire (HSQ) developed by Martin et al. (2003). Of particular interest to us here is the fact that what people understand by the very term humor will be influenced, and indeed limited, by the

*Corresponding author: Cliff Goddard, Griffith University School of Humanities Languages and Social Science, Nathan, Queensland, Australia, E-mail: c.goddard@griffith.edu.au Kerry Mullan, Global and Language Studies, RMIT University, School of Global, Urban and Social Studies, Melbourne, Victoria, Australia, E-mail: kerry.mullan@rmit.edu.au https://orcid.org/0000-0002-9078-0383 
language they speak. The English word humor lacks close and reliable equivalents in French (cf. Noonan 2011; Goddard 2017: § 3.3), and, as we show in this paper, the same applies to the English verb (to) joke. Conversely, English lacks close and reliable equivalents to French rigoler and plaisanter. To use Englishspecific words such as humor and joking as banner terms would be in effect to treat English as the "default language," as Wierzbicka (2014a) puts it, and in the process introduce an element of terminological and conceptual Anglocentrism.

This might strike some readers as a radical and/or unrealistic position. After all, humor studies is at present a predominantly Anglophone discipline (TranGervat 2016) and as such, routinely relies on English-based terminology even when describing interactions conducted in other languages. What is the harm in this? some might say. Or if there is a cost, is it not the cost we must pay for the benefits of having English as the global lingua franca for social science?

For the moment, we would like to defer these "big questions" until we have completed the main analytical project of our study, which is to undertake a contrastive lexical semantic analysis of a set of related verbs in English and French, using an essentially language-neutral methodology, namely, the Natural Semantic Metalanguage (henceforth: NSM) approach (Wierzbicka 1996; Peeters 2006; Goddard and Wierzbicka 2014; Ye 2017, and other works). It is not possible here to give a full account of the NSM theory but the key point is that it depicts the meanings of linguistic expressions using reductive cross-translatable paraphrases, i.e. paraphrases composed in a small, controlled vocabulary of crosstranslatable words. The methodology has emerged from a decades-long program of cross-linguistic semantic research, inaugurated by Wierzbicka (1972). The bibliography of NSM publications is extensive: dozens of books and hundreds of refereed journal articles and book chapters. For a searchable database of publications, see [nsm-approach.net]. For a general introduction to the approach and supporting online resources, see the NSM Homepage [short URL bit.ly/ 1XUoRRV]. Using the NSM methodology, we hope to show that the semantic and conceptual differences between French and English are greater than commonly assumed, but that there is a way in which the meaning content of these "local" categories and ways of speaking can be made explicit and accessible to cultural outsiders - not only from the languages concerned, but also from other languages. This should allow all parties to better understand and appreciate the perspectives of native speakers of the respective languages. The assumption here is that lexical categories, and ways of speaking generally, reflect routine ways of thinking and acting.

To move forward with any comparative or contrastive semantic project, one first needs to find common ground, a set of "common terms" (tertium comparationis). Research in the NSM approach has established that there is a common 
ground of shared meanings across all or most languages, in the form of semantic primes such as 'someone' and 'people,' 'say' and 'do,' 'think' and 'know, 'want' and 'feel,' 'good' and 'bad,' 'because,' 'if' and 'can,' among others (Goddard and Wierzbicka 2014; Peeters 2006). These common terms can be used to craft semantic explications, i.e. explanatory paraphrases, for words in either language and the resulting explications will be cross-translatable. The full list of semantic primes is given in Appendix A, in parallel English and French versions. Comparable tables have been drawn up for about thirty languages from a diversity of language families, geographical locations and cultural types. ${ }^{1}$ As we explain shortly, NSM research also suggests that the word 'laugh' has close equivalents in all or most languages, even though it is clearly not a semantic prime (NSM researchers consider it to be a "semantic molecule," see below).

Some key points about NSM semantic explications are as follows. An explication is intended to be a real paraphrase - fashioned from simple, cross-translatable words - of what a word or other linguistic expression means to a speaker or to a hearer. This has the twin benefits of warding off any implicit definitional circularity and at the same time making the explications accessible to native speakers without specialist training. The primary criteria for a good explication are three-fold: that it is phrased entirely in NSM acceptable lexicon and syntax; that it is coherent, i.e. it makes sense as a whole, and that it is compatible with the range of uses of the expression being explicated and satisfies native speaker intuitions about interpretation in context. Although these criteria allow one to evaluate proposed analyses, there are no fixed discovery procedures that lead directly from usage data to an optimal analysis. Essentially the NSM analyst faces the same challenge as a lexicographer, i.e. formulating a paraphrase that matches the range of use of a word, but with the constraint of doing so using a small controlled vocabulary of cross-translatable words.

In the present study, we (the authors) chose the terms for analysis following a search of various dictionaries and corpora for the most prominent and common verbs used when talking about humor in English and French. We then accessed naturally occurring examples of these words in several ways. For the English verbs joke and kid, we used a commercially available corpus service: WordBanks Online [http://wordbanks.harpercollins.co.uk]. This corpus also provided information about frequency of use and about collocations. For French, we used google searches to compile our own corpus of examples of rigoler and plaisanter. For both languages, we also drew on our own intuitions as native or near-native speakers (Goddard - English, Mullan - English and French), and

1 These can be consulted at https://www.griffith.edu.au/humanities-languages/school-human itieslanguages-social-science/research/natural-semantic-metalanguage-homepage/downloads. 
subsequently consulted informally with a number of colleagues with native or near-native language skills. Approximately one hundred examples of each term were examined, from which a number of representative examples appear below.

\section{Most English and French "humor" terms do not match}

It seems important to note again that the English word humor is not straightforwardly translatable into French, and that the French word humor is not semantically equivalent (the most general comparable meta-category in French is perhaps rire [lit. laughter], as in the title of Henri Bergson's famous treatise Le rire (1900)). We will not attempt, however, to take on this issue in the present study; see Goddard (2017) for an explication of the English humor. Here we set out instead to explicate the key verbs that are used in each language to depict pleasant "laughter-talk" with other people.

The general lay of the land is summarized in Figure 1. It shows a surprisingly large degree of non-correspondence between the two languages.

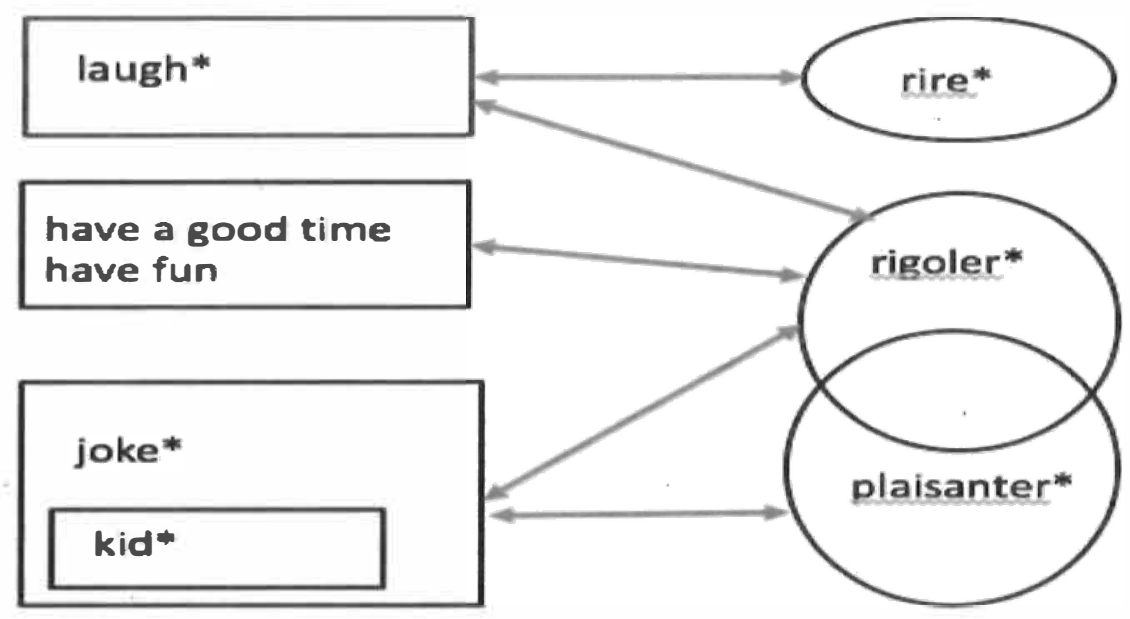

Figure 1: Range of use overlaps and translation correspondences between selected English and French "joking" verbs ( ${ }^{*}=$ explications presented in this paper).

At a rough first pass, the key points are as follows: (i) The verb French rigoler can be rendered into English in several ways (laugh, have a good time, joke or kid), depending on context. (ii) The English verbs joke and kid are closely related 
('kidding' seems like a specific manner of 'joking'), but neither has a close match in French. In translation, one can often use phrases involving either rigoler or plaisanter, but both of these seem to have more general meanings even than joke. (iii) French plaisanter in particular has a broad meaning to do with saying or doing things for "pleasure," without any very close connection to laughing. It is etymologically related to the adjective plaisant 'pleasing' and the verb plaire 'to please.' In view of these differences in this study we concentrate on the meanings and uses of English joke and kid, and French rigoler and plaisanter.

We do accept, however, that there is one "perfect match" between the French and English words displayed in Figure 1, namely, between English laugh and French rire. This is important as it is widely assumed - in our view, rightly so - that the concept of 'laughing' is implicated in many "humor" concepts and practices (Provine 2000; Partington 2006; Chafe 2007; Goddard 2016). NSM researchers have argued for some years that it is a reasonable hypothesis that a close lexical equivalent to 'laugh' exists in all or most languages (Wierzbicka 2014b; Goddard 2017; Goddard and Wierzbicka 2016), and can therefore be considered a semantic molecule [m] for NSM purposes. ${ }^{2}$ Since this proposal has been dealt with in previous publications, we will take it for granted here. An explication for English laugh and French rire is provided, along with a summary discussion, in Appendix B. What it means for present purposes is that we are free to employ the molecule 'laugh' in our explications, along with semantic primes, with confidence that the explications will be fully crosstranslatable. To reinforce this point, at least for French, we provide all explications in dual English and French versions.

\section{The French perspective: Rigoler in its three senses}

Rigoler is both extremely common and extremely versatile in contexts in which, in English, one would use words like 'laugh,' 'joke,' 'have fun. ${ }^{3}$ A google search

2 Needless to say, this claim in no way denies that linguacultures can vary greatly in their attitudes towards laughing, or in how laughing is regulated, encouraged or suppressed (cf. Wierzbicka 1999: 217ff).

3 Historically, it seems that rigoler first appeared in the late thirteenth century meaning 'to greatly enjoy oneself; by 1655 it had also come to mean to eat and enjoy time together with friends, to let oneself go a little'; and not until 1821 did it come to mean 'laugh' (Centre National de Ressources Textuelles et Lexicales http://www.cnrtl.fr/etymologie/rigoler). While not strictly relevant, the etymologies of the terms under examination show that these terms were all historically quite different, which may help to shed light on some of the current uses of rigoler. 
[31.01.17, google.fr] returned more than 5 million search results. Rigoler conjures up images of sharing special and enjoyable moments with friends. On our analysis, the verb rigoler currently has three distinct-but-related meanings, i.e. the word is polysemous. Here it should perhaps be pointed out that in cases of lexical polysemy, such as this, each meaning requires a separate explication. ${ }^{4}$

MEANING (A). This meaning designates real, hearty laughing. In support of the first point ('real'), it can be noted that the verb can be modified by an adverb like fort 'loud,' as in (1). In support of the second point ('hearty'), it can be noted that it is not possible to combine rigoler with adverbial modifiers such as nerveusement 'nervously' or de façon incontrôlable 'uncontrollably,' etc. (whereas such modifiers are perfectly acceptable with rire 'laugh').

(1) Tu adores raconter n'importe quoi et rigoler -super fort - n'importe où et n'importe quand. ${ }^{5}$

'You love telling stories and rigoler a lot, whenever and wherever, and super loud.’

(2) Du coup j'ai décidé de vous faire un petit point hebdo. Et où je commente les images que je poste, qu'on rigole un peu, deux secondes. ${ }^{6}$

'So I decided to do a little weekly update for you, where I'll comment on the photos I post so we can rigoler a bit for a second or two.'

(3) Mon copain et moi on est très complices, on rigole beaucoup pour tout et n'importe quoi sans que ce soit vraiment possible d'expliquer. ${ }^{7}$

'My boyfriend and I have a lot in common, we rigole a lot about anything and everything without really being able to explain why.'

(4) J'ai beaucoup rigolé en regardant ce film.

'I laughed a lot while watching this movie.'

\footnotetext{
4 Though there is no space here to discuss the matter, the NSM paraphrase technique provides a much-needed procedure for deciding between two analytical alternatives which often present themselves when a word has a wide range of use: semantic generality (vagueness), on the one hand vs. polysemy (distinct meanings), on the other. In the NSM system, if the analyst wishes to posit generality, he or she has to produce a single semantic explication and demonstrate that it accounts for the range of use, without overpredicting. If the analyst wishes to posit polysemy, he or she has to produce two (or more) distinct explications, and argue that they cannot plausibly be collapsed into one (cf. Goddard 2000).

5 http://www.garancedore.fr/theminis/happy-40th-birthday-g/.

$6 \mathrm{http}: / /$ www.garancedore.fr/2015/12/15/the-update/.

7 http://forums.madmoizelle.com/sujets/rigoler-avec-son-copain.58218/.
} 
Furthermore, there is another very significant aspect to rigoler, suggested by the fact that when used in this sense, rigoler usually refers to an "enjoyable social situation" of verbal interaction. This is evident in examples (1)-(3) above, though not in example (4). ${ }^{8}$ Typically, rigoler depicts behavior that is prompted by a brief remark (including one's own), something one does together with others, and in which one plays an active role. This is evident in the causative phrase faire rigoler ('to make someone laugh'), for example Je l'ai fait pour te faire rigoler! ('I did that to make you laugh!'), which corresponds only to meaning [A].

All these aspects of the meaning of rigoler are captured in explication $[\mathrm{A}]$. Notice the third line of the explication introduces a prototypical social situation, by referring to how 'people in a place often feel when ...'

[A] Elle rigole (à cause de quelque chose / because of something) [meaning a]

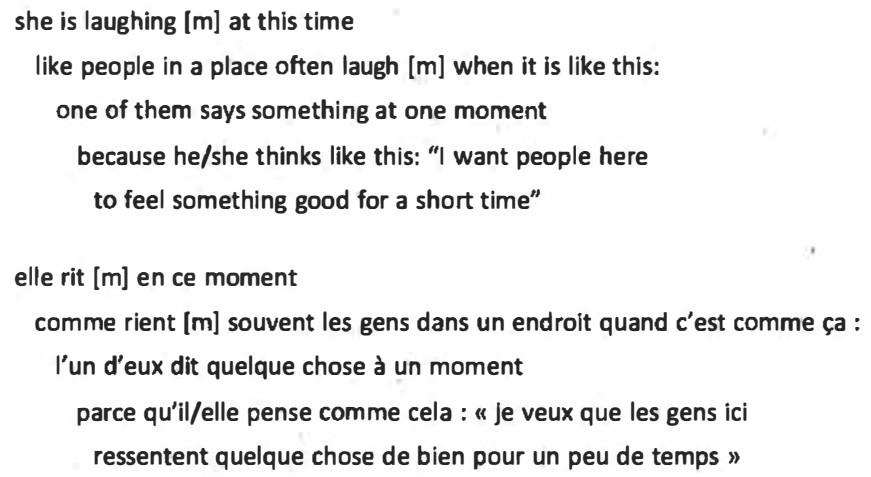

To put it informally, the idea behind this explication is that rigoler evokes a situation involving 'people in a place' being caused to feel something good when 'one of them says something at one moment' (suggesting a brief, spontaneous remark) with the intention of causing everyone there 'to feel something good for a short time.' Note that this phrasing is compatible with the speaker being included in the general "good feeling."

MEANING (B). The second meaning of rigoler usually occurs with a plural subject, and often with an adverb like bien 'good' or vraiment 'really.' It does not depict laughing as such, but is focussed rather on the "fun" aspect of being together with other people over a period of time during which there are many light-hearted moments, typically involving laughing. The following are some representative examples.

8 Expressions like rigoler dans son coin and rigoler tout seul (both roughly 'to laugh by/to oneself) do exist, but the modifiers reinforce the assumption that normally a social setting is expected. 
(4) On a bien rigolé (ce soir, hier etc.).

'We had a great time, such a fun time (tonight, yesterday etc.).'

(5) On a bien rigolé hier soir! Merci à vous! [George \& Dragon, Toulouse March 19, 2016. Toulouse, France (Facebook post) ${ }^{9}$

'We had a great time last night. Thanks everyone!'

(6) “on rigole bien !!!!" Trip Advisor

5/5, Discovery Dive Centre, Ko Samui, Thailand, reviewed 16 February $2016 .^{10}$ 'You have (as in 'one has') a great time!!!!'

The meaning of rigoler in this expression can be captured in explication [B].

[B] On a bien rigolé (ce soir). [meaning b]

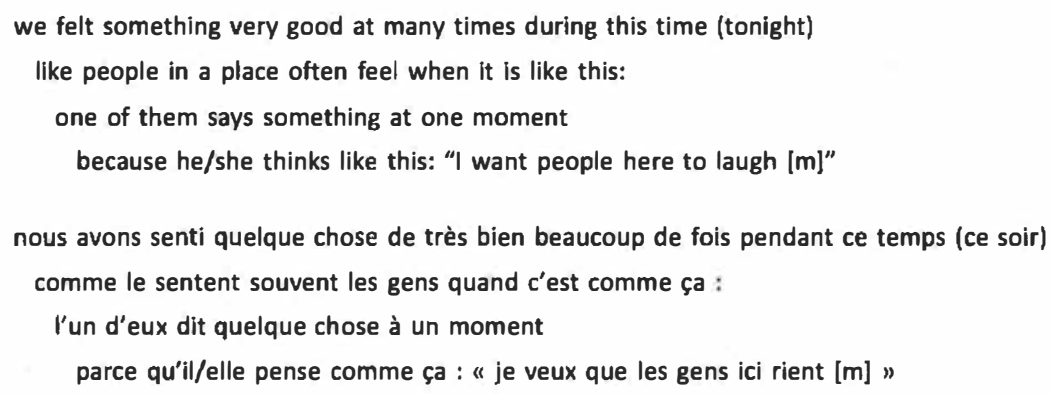

Comparing explications $[\mathrm{A}]$ and $[\mathrm{B}]$, one can see that they are largely fashioned from the same materials. This explains or accounts for the polysemic relationship between the two senses, and for the strong intuitive relationship between them. One small point of difference is that the "feeling-focused" sense in [B] depicts recurring 'very good feelings' over the time in question.

MEANING (C). The third meaning of rigoler is focussed on saying and it often occurs in the expression Je l'ai dit pour rigoler ('I said it to rigoler'), which is functionally equivalent to English expressions such as: I meant it as a joke, or I said it for ( $a$ bit of) fun. (The verb plaisanter is also used similarly; see Section 5.)

(7) Je l'ai dit pour rigoler.

'I said it just for rigoler (for fun).'

9 https://www.facebook.com/georgeanddragonpub/videos/1159948364016611.

10 https://www.tripadvisor.com/Attraction_Review-g1179396-d547537-Reviews-Discovery_ Dive_Centre-Bophut_Ko_Samui_Surat_Thani_Province.html\#photos;aggregationId=8albu mid $=101 \&$ filter $=7$. 
(8) Quand je suis allé voir le film Titanic (...) j'ai dit pour rigoler : "Ah mais on connait déjà la fin, le bateau va couler !"11

'When I went to see the film Titanic (...) I said for a bit of fun: "Oh, but we already know the ending, the boat's going to sink!"'

The emphasis in these expressions is on why someone says something (typically, something spontaneous); namely, with the intention of causing 'someone here' to briefly feel something good 'like people often feel when they laugh." ${ }^{12}$

[C] Je l'ai dit pour rigoler (lit. I said it for rigoler) [meaning c]

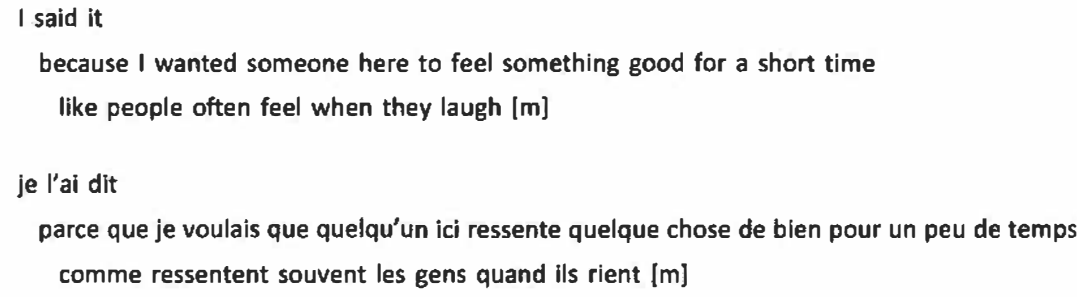

The meaning of rigoler explicated in [C] can also appear with first or second person subjects in the formulaic expressions Tu rigoles! 'You're joking/kidding!,' or Je rigole ! '(I’m) (just) kidding!,' whose functional equivalents in English involve the verbs joke or kid. Such uses are very common, especially in informal speech. ${ }^{13}$ We will return briefly to these functions of rigoler in Section 5, when we consider comparable expressions with plaisanter.

We now move to English, whose premier verbs in this space are joke and kid.

\section{The English perspective: joking and kidding}

Before beginning our treatment, it may be helpful to emphasize that semantic explications are intended to capture the meanings of words: they are not depictions of real interactions or the real intentions of particular speakers.

11 http://danstonchat.com/15967.html.

12 This latter component corresponds closely to English expressions involving the word amuse or its derivatives, e.g. amusing, amusement (cf. Goddard 2017), and their French counterparts: amuser, amusant, amusement respectively.

13 When used in this meaning with a third person subject, there is often a rather negative pragmatic flavor. Il/elle rigole (lit. he/she rigole) conveys something close to "He/she can't be serious" or even "He/she's taking the piss." It can be used when what is being referred to is clearly ridiculous or out of the question (and not at all humorous). 
This is important to note, because the words considered below can be used by speakers on occasion as "cover" for nasty or hurtful intentions; for example, when someone says I was just joking or I was only kidding to mask or explain away a hostile comment, or as an attempt to ward off offence. It is essential to distinguish between pragmatic function and semantic meaning (cf. Haugh 2016). In fact, the words joking and kidding can only be used to do this kind of pragmatic work because of their semantic meanings, i.e. because they depict speech acts which are well-intentioned.

We will now examine the two English verbs: joke and kid. Compared with rigoler (and with plaisanter, as we will see shortly), both are rather focused on "saying."

\subsection{Joking}

Of the two verbs to be considered, (to) joke (and derivatives such as joking and jocular) clearly out-shadows (to) kid in its importance as a topic word in cultural anthropology, sociology, and social psychology (cf. the extensive anthropological literature on "joking relationships," for example; Radcliffe-Brown 1940; Carty and Musharbash 2008). This is not directly relevant to our immediate task, though, which is to examine the meaning of the verb joke as it is used in everyday English. It goes without saying that we need to distinguish between "telling a joke" (with its associated noun joke(s)) and "joking" as an activity, which may not involve jokes at all. (This distinction was less clear in the 1660s between the noun form joque, "a jest, something done to excite laughter," from Latin iocus "joke, jest, sport, pastime," and the verb "to make a joke," from 'joke' (n.) or else from Latin iocari "to jest, joke," from iocus "joke, sport, pastime." ${ }^{14}$ ) Three representative examples are given in (10)-(12) below.

(10) They were laughing and joking and seemed very relaxed with one another. [WordBanks]

(11) He likes to joke with his customers (friends, team mates, workers, etc.).

(12) Britney fans immediately took to Twitter to remind Perry that joking about mental health is never a good move, launching the \#KatyPerrylsOver hashtag. ${ }^{15}$

14 Online Etymology Dictionary http://www.etymonline.com/index.php?term=joke.

$15 \mathrm{http}$ ://www.huffingtonpost.com.au/entry/katy-perry-britney-spearsgrammys_us_ 58a10115e4b03df370d77f89. 
Explication [D] below depicts "joking" as, roughly speaking, a way of saying things which is prototypically expected and intended to cause 'people here' to want to laugh and to feel good for a short time, i.e. it anticipates an "audience reaction."

Note that the expression 'people here' could include the speaker, as well as any others present.

[D] He was joking.

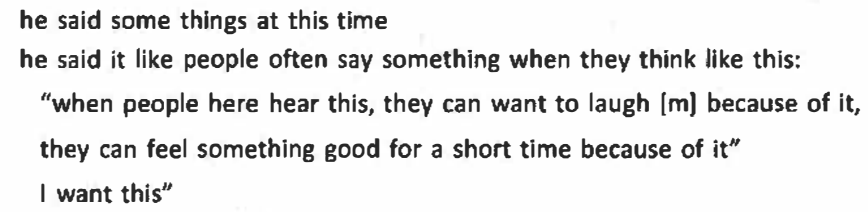

Explication [D] supports the intuition that the meaning of joking involves laughing (strictly speaking, wanting to laugh) as an anticipated outcome. This intuition is also supported by collocational data from WordBanks corpus, in which the expression 'laughing and joking' (as in example (10) above) is common, with 200 tokens. On the other hand, in the same corpus, the expression 'laughing and kidding' does not occur at all.

\subsection{Kidding}

Although the verb (to) kid may not seem, from an impressionistic point of view, nearly as important as (to) joke, it is remarkably frequent, due partly to its presence in numerous formulaic expressions such as No kidding, You've got to be kidding, etc. ${ }^{16}$ Some examples of (to) kid in a descriptive function follow.

(13) "Daddy's just kidding, honey," she said in a soothing tone, "Of course there aren't any devils on Moose Island" ... [WordBanks]

(14) It [the email) said: "I left you a surprise for you to remember me by. Ha ha, just kidding." [WordBanks]

16 The term (to) kid is much younger than (to) joke however: it appeared in 1811, meaning "to coax, wheedle, hoax," probably via the notion of "treat as a child, make a kid of," and in 1839 came to mean "to tease playfully"; No kidding! did not appear until 1914. Online Etymology Dictionary http://www.etymonline.com/index.php?allowed_in_frame=0\&search=kid. 
(15) There is a lot of joking and kidding around here on a daily basis, which keeps things lively in our office. ${ }^{17}$

Although there is clearly a close relationship between kidding and joking, explication [E] depicts kidding as more complex than joking in the implied "mindset" of the speaker, and as consciously directed towards a specific addressee. The speaker's (apparent or ostensible) intention is for the addressee to be momentarily disbelieving and confused, before realizing what is going on and feeling "amused" (i.e. briefly feeling something good as people often feel when they want to laugh, cf. Goddard 2017). This particular intention helps explain why in interactional data, there is often slightly delayed laughter, following instances of declared kidding (Haugh 2016).

[E] He was kidding (when he said it).

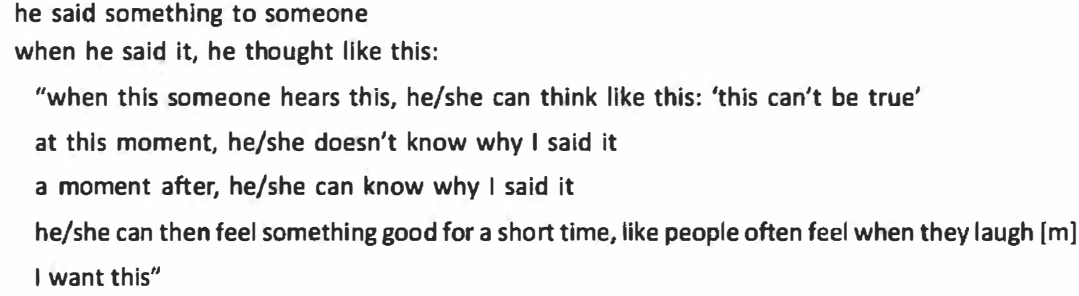

The explication likewise helps to account for the high frequency, in interactional data and in corpora, of follow-ups such as Just kidding and Only kidding ${ }^{18}$ and to explain common fixed formulas for expressing real, feigned or ironic "disbelief," e.g. You're kidding me, You've got be kidding, and related expressions in the negative, e.g. No kidding and I'm not kidding, whereby the speaker vouches for his or her seriousness. ${ }^{19}$

\section{French - plaisanter}

Etymologically, the verb plaisanter is related to the adjective plaisant 'pleasing,' from the verb plaire 'to please.' According to the standard Robert dictionary,

17 http://www.supportiveis.com/supportive-insurance/culture/.

18 It should be noted, though, that formulas like Just/only kidding and Just/only joking are not used exclusively as "repairs," to use the terminology of Conversation Analysis. Haugh (2016) shows that they are also commonly used to close off the non-serious interlude, and to signal an intention to return to seriousness.

19 A related usage in found with reflexive pronouns, e.g. I was kidding myself, You're kidding yourself, but this must be a distinct meaning, approximately the same as I was fooling myself. Incidentally, no such usage is possible in French with either rigoler or plaisanter. 
plaisanter was used as early as 1531 to mean « badiner, faire quelque chose pour amuser " (to jest/joke/banter, to do something to amuse). It was not until 1690 that plaisanter (pour plaisanter) came to be used in the sense comparable to that of pour rigoler, as explicated in [C] above. ${ }^{20}$

The contemporary verb plaisanter is clearly broader in its reach than English (to) joke, while still having some key components in common with it. As mentioned in Section 3, the expression pour plaisanter occurs very frequently in French: a google search [google.fr. 31.01.17] yielded 852,000 results (approximately twice as many as pour rigoler). Examples (16) and (17) illustrate one of the most common uses of (pour) plaisanter, i.e. to say something as a joke, not to be taken seriously.

(16) On s'entendait vraiment bien et pour plaisanter je lui ai dit : "Tu ne veux pas changer de boite et venir travailler avec nous ?"21

'We got along really well and for a joke (pour plaisanter) I said to him: "Do you want to change companies and come and work with us?'

(17) Ils achètent beaucoup sur le web, et parfois des produits qu'ils n'oseraient pas acheter en magasin. Nous appelons pour plaisanter ces produits les "produits de la honte ", comme les très efficaces soins autobronzants ou les produits de coloration, qui répondent à un vrai besoin, mais ne sont pas encore totalement entrés dans les mours. ${ }^{22}$

'Men buy a lot on the internet. Sometimes, this is how they get products that they would not dare pick up in a store - what we jokingly (pour plaisanter) call 'the products of shame.' These include things like tanning and tinting products, which are extremely effective and meet a genuine need, but which are not yet totally socially acceptable.'

In the example below, pour plaisanter is less about saying, and is better conveyed as 'to enjoy a good time.'

(18) "Les Voiles " est le lieu idéal pour plaisanter autour d'un verre entre amis et un décor magique pour les diners romantiques. ${ }^{23}$

'The Veils [beach restaurant/cafe] is the ideal place to enjoy a good time (pour plaisanter) over a drink with friends surrounded by magical décor for romantic dinners.'

20 Centre National de Ressources Textuelles et Lexicales http://www.cnrtl.fr/etymologie/ plaisanter.

21 http://www.frenchavecnous.com/french-podcasts-deux-freres/.

22 https://www.monthly-digest-loreal.com/article/english-selling-beauty-to-men/.

23 http://hotelparticulierbeziers.com/diner-sur-un-air-de-vacances-et-de-depaysement-a-beziers/. 
Another use of this expression is shown in example (19), where a news report uses n'est pas là pour plaisanter ("is not there for plaisanter") to render the English idiom '(he) means business.'

\section{(19) Mcllroy n'est pas là pour plaisanter à Hazeltine}

Rory McIlroy a terminé le premier jour de la Ryder Cup 2016 en beauté avec un eagle et a ensuite célébré sa victoire en montrant qu'il n'était pas là pour plaisanter cette semaine à Hazeltine National.

'McIlroy means business at Hazeltine'

'Rory McIlroy finished one day of the 2016 Ryder Cup with a brilliant eagle and then gave a celebration that showed he means business this week at Hazeltine National. ${ }^{24}$

Explication $[\mathrm{F}]$ below suggests that plaisanter can be used for both saying and doing. It is significantly more "sociable" than joking in two ways: first, it envisages a situation in which people 'are with some other people for some time,' and, furthermore, that 'they feel something good towards these other people at this time.'

[F] He said/did it pour plaisanter.

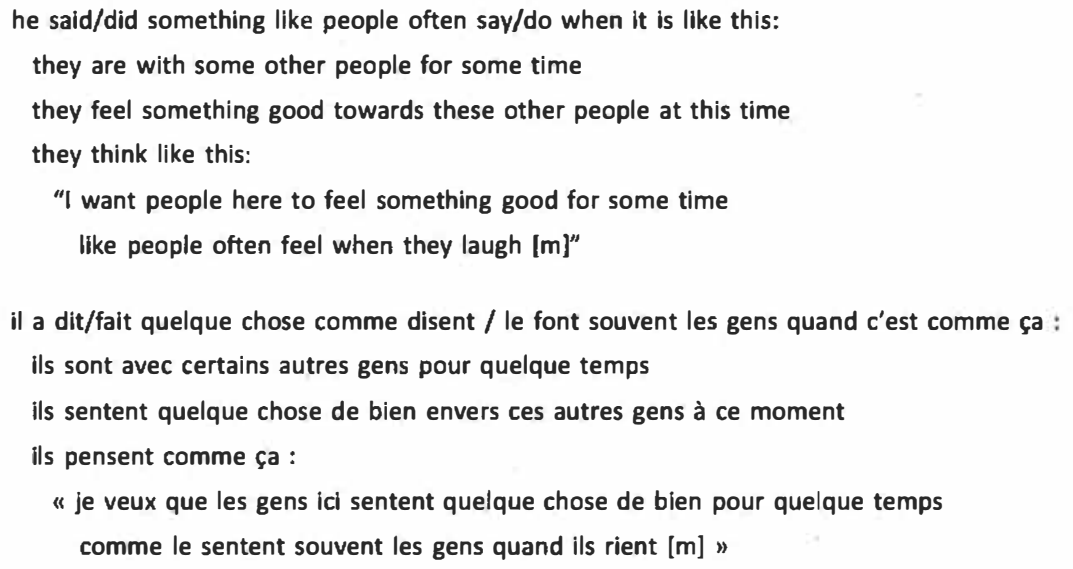

Plaisanter also differs from rigoler in that it is not about creating "special moments," but rather about creating a pleasant and relaxed atmosphere over an extended period of time. This use is evident in the following extract from a

24 http://www.rydercup.com/news-media/europe/mcilroy-means-business-hazeltine. 
French magazine article, where the question is whether creating such an atmosphere is acceptable in a job interview.

(20) Plaisanter lors d'un entretien d'embauche, bonne ou mauvaise idée?

Cela peut sembler dangereux de faire preuve d'humour ${ }^{25}$ pendant un entretien d'embauche, mais il est aussi erroné de penser que les candidats sérieux scorent généralement mieux. Bien au contraire, une plaisanterie bien placée, améliore vos chances. ${ }^{26}$

'Plaisanter during a job interview: good or bad idea?'

'It might seem dangerous to show a sense of humour in a job interview, but it's also a mistake to think that serious candidates generally score better. On the contrary, a well-placed plaisanterie ${ }^{27}$ increases your chances.'

Example (20) is also interesting in the sense that the question is being asked at all in this article. In many Anglo contexts (for example, in Australia, cf. Goddard 2009), it seems to us that most people would readily agree that a measure of "humor" could work well in many job interviews. Equally interesting, in our view, is the answer given in this French article, for until recent years we feel sure that plaisanter in most job interviews would have been more frowned upon in France, due to the French respect for the formality and power asymmetry of this gatekeeping encounter. ${ }^{28}$

This completes our treatment of the contrastive lexical semantics of French rigoler and plaisanter, as opposed to English (to) joke and (to) kid. It remains to sum up and to draw out the more general conclusions and implications.

25 The original French "faire prevue de l'humour" is not accurately conveyed by 'show a sense of humor' here, since, as mentioned, the very meaning of l'humour is not the same as 'humor,' but is coming to be influenced by the English meaning due to language-culture contact; unfortunately this discussion is beyond the scope of this paper.

$26 \mathrm{http} / / / \mathrm{www}$.jobat.be/fr/articles/plaisanter-lors-d-un-entretien-d-embauche-bonne-oumauvaise-idee/.

27 The noun form of the verb plaisanter, commonly translated as "funny comment" or "joke." 28 Cf. Lipovsky (2012) for a detailed analysis of the successful use of humor in a French job interview. While Lipovsky found that the humor ultimately fostered an affiliation between the interviewer and interviewee, it should be noted that seven out of the total nine instances of humor were initiated by the interviewer, and that he did not laugh at the two instances of humor initiated by the interviewee. 


\section{Conclusion}

We will first review the immediate implications of the lexical semantic differences between the languages, then raise the question of how and to what extent the particularities of each language can be linked to broader cultural themes, and finally we will briefly highlight the further work required in terms of the methodological and theoretical implications for the field currently known as "humor studies."

First then, what do we learn from this exercise in contrastive lexical semantics? If we entertain the idea that words are "pointers" to ways of thinking, it is possible to interpret our results as telling us something about the habitual ways of thinking of the "Anglos" (or Anglo-Saxons, as they are often termed in the Francophone world, cf. Chabal 2017) and "the French."29

In French, as we have seen, the main verbs in the broad area of "laughing with other people" are plaisanter and rigoler. The French, it would seem, are interested in pleasurable social interactions, in people being together, making short spontaneous remarks, sharing the resulting good feelings, and often laughing (cf. Béal and Mullan 2013, 2017). ${ }^{30}$ Both the verbs plaisanter and rigoler cast a wider net, so to speak, than English joke or kid, capturing something like pleasant light-hearted interaction.

In English, the main verb in the area of "laughing with other people" is (to) joke. Compared with plaisanter and rigoler, it is more speaker-oriented, in the sense that although the presence of other people is important as an audience, there is greater emphasis both on the individual as a performer ${ }^{31}$ and on the verbal mode. As for the verb (to) kid, its presence as a specialized lexical item betokens the existence of a specific "micro-genre" of English verbal interaction, based, broadly speaking, on momentary deception.

Coming now to broader cultural themes, we think it is helpful to ask what cultural key words there may be, in their respective languages, that can be linked with the verbs examined in this study. We use the term "cultural key words" in the sense of Wierzbicka (1997), namely, culture-rich and translationresistant words which occupy focal points in cultural ways of thinking, acting,

29 With similar caveats as those necessarily applied to the term "Anglos," we refer primarily to French speakers from France (sometimes called Franco-français or Français de France).

30 There may be a closer match between French blaguer and English tell a joke.

31 A further piece of evidence is that in English joker is a commonly used noun, but rigoleur and rigolard are not, and plaisantin is negatively charged (roughly, 'someone who thinks they are funny'). 
feeling, and speaking and which "reflect the core values of a given culture" (cf. Goddard 2015).

For English, an abundance of evidence indicates that the word humor itself, and also the expression sense of humor, deserve to be counted among the key words of Anglo culture (Wierzbicka 2010: 184-192; Goddard 2017). To mention only one such piece of evidence, there is the fact (remarkable from the viewpoint of some other cultures) that Anglo speakers rank a sense of humor as such a highly-valued character trait that it features in obituaries, as well as in personal ads and job search criteria. In view of its key word status, it is hardly surprising that it makes perfect sense, from an Anglo point of view, to tether a whole field of study to the word humor.

However, as noted several times, French has no direct correspondent to the English word humor, and there does not appear to be any single French cultural key word that can be linked with the interactional style implicit in plaisanter and rigoler. (This is supported by the fact that the French talk about l'humour anglais, "English humor," as distinct from their own.) Such a term, if there were one, would need to combine elements of several concepts, such as amusement - from the verb s'amuser, roughly, 'to enjoy oneself' - with a clear link between laughter, having a good time, and sharing special moments with friends. On the other hand, we would like to note the relevance to French interactional style of the concept of esprit, a uniquely French word with a vast range of meanings, including 'spirit,' 'intellect' and 'wit.' The most relevant meaning of esprit here is that of "wit," which includes a strong implication of intelligence, as well as flair and linguistic spontaneity designed to amuse and delight one's interlocutors. Esprit is common in the wordplay so favored by French speakers in their interactions with each other, as outlined in Béal and Mullan (2013, 2017).

Finally, considering the implications for "humor studies" more generally, we would like to start with the obvious point that in French society there is no discourse about "humor" and no talk about "joking," either. When the French talk about "laughing with other people," such discourses are conducted using words such as rigoler and plaisanter, where the emphasis is on pleasurable social interactions. So when French social behaviors are described solely in foreign (i.e. Anglo) terms, without reference to these French words and to their attendant ways of thinking, is it not the case that French concepts and ways of thinking are being "over-written" by English? (For example, despite some overlaps, we are sure that a very different picture would emerge if we looked at esprit in conversation, instead of conversational humor.) This leads us to reflect whether, and to what extent, the predominantly Anglophone nature of academic 
discourse in humor studies may have skewed the development of the field (cf. Goddard 2018).

Analyses such as the present one are useful because they show that each language captures some, but not all, aspects of "humor" as it is understood by humor studies researchers. (Future such analyses might include adjectives used to talk about humor, rather than verbs as in the present study.) By comparing the words and expressions in two or more languages, researchers may be able to identify a wider range of humorous experiences relevant to people's daily lives. These may be useful in future studies of individual differences of humor styles or other humor-related behaviors, such as those outlined in the Humor Studies Questionnaire. Indeed, future research might include examining possible implications for the self-report measures in English that are frequently used to assess individual differences in humor via the HSQ.

It should therefore be clear from the present study that "translation problems" (as they are often seen) are not necessarily problems. On the contrary, they are prompts that there is work to be done. They present opportunities to deconstruct the culture specific terminologies of particular languages, resolve them into common, cross-translatable terms, and in the process learn much about what is similar and what is different in how particular languages construe social interaction.

Acknowledgements: The authors would like to thank two anonymous reviewers for their helpful comments on this paper. We would also like to thank Sophia Waters for research assistance with French, and Helen Leung for research assistance with WordBanks (English). We are especially grateful to Anna Wierzbicka and Bert Peeters for consultation about the explications, and to Diane de Saint Léger for her helpful comments. Earlier versions of this paper were presented at the Australasian Humour Studies Network Conference, Federation University Australia, Ballarat, February 3, 2017, and the Workshop on Minimal English and NSM Semantics, Australian National University, Canberra, March 18, 2017. 


\title{
Appendices
}

\section{Appendix A: Semantic Primes, French and English equivalents (after Peeters 2015) ${ }^{32}$}

\author{
JE, TU, QUELQU'UN, QUELQUE CHOSE CHOSE, GENS, CORPS \\ substantives \\ I, YOU, SOMEONE, SOMETHING THING, PEOPLE, BODY \\ TYPES, PARTIES \\ KINDS, PARTS \\ relational \\ substantives \\ CE, LA MEME CHOSE, AUTRE \\ determiners \\ THIS, THE SAME, OTHER ELSE \\ UN, DEUX, CERTAINS, TOUS, BEAUCOUP, PEU \\ quantifiers \\ ONE, TWO, SOME, ALL, MUCH MANY, LITTLE FEW \\ evaluators \\ GOOD, BAD \\ GRAND, PETIT \\ descriptors \\ BIG, SMALL \\ SAVOIR, PENSER, VOULOIR, NE PAS VOULOIR, SENTIR, VOIR, ENTENDRE \\ KNOW, THINK, WANT, DON'T WANT, FEEL, SEE, HEAR \\ DIRE, MOTS, VRAI \\ SAY, WORDS, TRUE \\ FAIRE, ARRIVER, BOUGER \\ DO, HAPPEN, MOVE \\ mental predicates \\ speech \\ actions, events, \\ movement

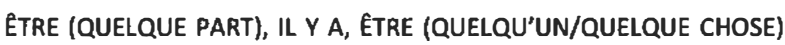 \\ location, existence, \\ BE (SOMEWHERE), THERE IS, BE (SOMEONE/SOMETHING) \\ specification \\ (EST) A MOI \\ possession \\ (IS) MINE \\ VIVRE, MOURIR \\ life and death \\ LIVE, DIE \\ QUAND MOMENT FOIS, MAINTENANT, AVANT, APRÈS, LONGTEMPS, PEU time \\ DE TEMPS, POUR QUELQUE TEMPS, INSTANT \\ WHEN TIME, NOW, BEFORE, AFTER, A LONG TIME, A SHORT TIME, FOR \\ SOME TIME, MOMENT
}

(continued)

32 https://www.griffith.edu.au/humanities-languages/school-humanities-languages-social science/research/natural-semantic-metalanguage-homepage/downloads. 
(continued)

OÙ ENDROIT, ICI, AU-DESSUS, AU-DESSOUS, LOIN, PRĖS, CO̊TÉ, DANS, TOUCHER

WHERE PLACE, HERE, ABOVE, BELOW, FAR, NEAR, SIDE, INSIDE, TOUCH

NE ... PAS, PEUT-ETRE, POUVOIR, A CAUSE DE, SI

NOT, MAYBE, CAN, BECAUSE, IF

TRÈS, PLUS

VERY, MORE

COMME FAÇON

LIKE AS WAY place

logical concepts

intensifier, augmentor

similarity

Notes

- Exponents of primes can be polysemous, i.e. they can have other, additional meanings.

- Exponents of primes may be words, bound morphemes, or phrasemes.

- They can be formally complex.

- They can have language-specific combinatorial variants (allolexes, indicated with ).

- Each prime has well-specified syntactic (combinatorial) properties.

\section{Appendix B: Laugh'= 'rire': A universal or near-universal building block for «humor» concepts}

The explication below is adapted from one proposed by Wierzbicka (2014b) for English 'laugh.' We claim that it is equally valid for French rire. Note that the first component includes a durative element 'for some time,' which indicates that the explication is specifically tailored for "durative/imperfective" uses of laugh. A separate, closely related, explication is needed for "perfective/punctual" uses, and for contexts like 'he laughed nervously' or 'she laughed scomfully' (Goddard 2017).

The explication falls into three sections, labelled here (a), (b) and (c). Brief comments follow the explication.

Mary is laughing (= Marie rit)

a. this someone (i.e. Mary) is doing something for some time (at this time) something is happening to some parts of this someone's body because of it

b. people often do this when they feel something good for a short time because they think like this:

"something is happening here now

things like this don't happen very often

people here can feel something good because of it"

c. when someone does it, it is like this:

- some parts of this someone's mouth [m] move for some time 


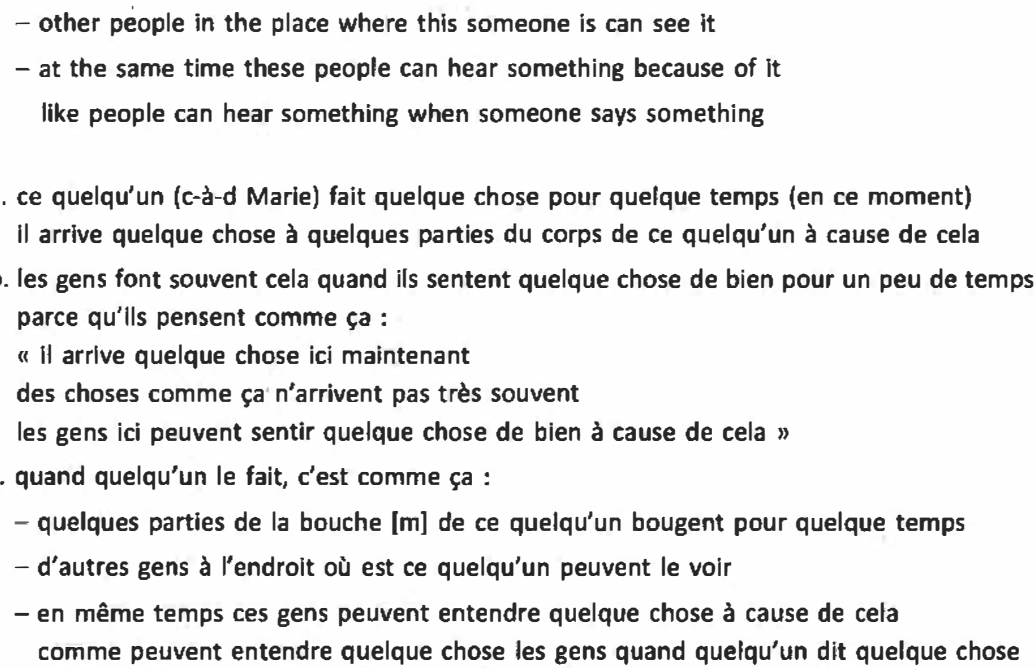

\section{Key points}

- Section (a) consists of very general components (termed Lexicosyntactic Frame in NSM parlance, cf. Goddard and Wierzbicka (2016)), shared with various other verbs, notably (to) $c r y$.

- Section (b) is a Prototypical Scenario. The word 'often' in the first line of course implies 'not always.' The scenario depicts laughing as typically triggered by a person experiencing a brief good feeling occasioned by subjective awareness that (roughly put) something "unusual" is happening here and that 'people here can feel something good' because of it.'

- Section (c) is a description of the physical "mechanics" of laughing, which includes visual movement of the mouth and (often) an audible "vocal" sound. In some languages, the components about "audibility" vary slightly, cf. Chinese xiao 'laugh/smile.'

- The very final. line hints at something like "expressiveness."

\section{References}

Béal, Christine \& Kerry Mullan. 2013. Issues in conversational humour from a crosscultural perspective: Comparing French and Australian corpora. In Bert Peeters, Kerry Mullan \& Christine Béal (eds.), Cross-culturally speaking, speaking crossculturally, 107-140. Newcastle upon Tyne: Cambridge Scholars.

Béal, Christine \& Kerry Mullan. 2017. The pragmatics of conversational humour in social visits: French and Australian English. Language and Communication 55. 24-40. 
Bergson, Henri. 1900 [1940]. Le rire : essai sur la signification du comique. Paris: Presses Universitaires de France.

Carty, John \& Yasmine Musharbash. 2008. You've got to be joking: Asserting the analytical value of humour and laughter in contemporary anthropology. Anthropological forum 18(3). 209-217.

Chabal, Emile. 2017. Les Anglos-Saxons. Aeon 18th September 2017. https://aeon.co/essays/ the-anglo-saxon-is-not-american-or-british-but-a-frenchalter-ego (accessed 21 September 2017).

Chafe, Wallace. 2007. The Importance of Not Being Earnest. The feeling behind laughter and humour. Amsterdam: John Benjamins.

Goddard, Cliff. 2000. Polysemy: A problem of definition. In Yael Ravin \& Claudia Leacock (eds.), Polysemy: Theoretical and Computational Approaches, 129-151. Oxford: Oxford University Press.

Goddard, Cliff. 2009. 'Not taking yourself too seriously' in Australian English: Semantic explications, cultural scripts, corpus evidence. Intercultural Pragmatics 6(1). 29-53.

Goddard, Cliff. 2015. Words as carriers of cultural meaning. In John R. Taylor (ed.), The Oxford handbook of the word, 380-400. Oxford: Oxford University Press.

Goddard, Cliff. 2017. Ethnopragmatic perspectives on conversational humour, with special reference to Australian English. Language \& Communication 55. 55-68.

Goddard, Cliff. 2018. “Joking, kidding, teasing": Slippery categories for cross-cultural comparison but key words for understanding Anglo conversational humor. Intercultural Pragmatics 15(4). 487-514.

Goddard, Cliff \& Anna Wierzbicka. 2014. Words and meanings: Lexical semantics across domains, languages, and cultures. Oxford: Oxford University Press.

Goddard, Cliff \& Anna Wierzbicka. 2016. Explicating the English lexicon of "doing and happening". Functions of Language 23(2). 214-256.

Haugh, Michael. 2016. "Just kidding": Teasing and claims to non-serious intent. Journal of Pragmatics 95. 120-136.

Lipovsky, Caroline. 2012. Fostering affiliation through humour in a job interview. Sociolinguistic Studies 6(1). 149-172.

Martin, Rod. 2006. The psychology of humor: An integrative approach. Burlington, MA: Elsevier Academic Press.

Martin, Rod A., Patricia Puhlik-Doris, Gwen Larsen, Jeanette Gray \& Kelly Weir. 2003. Individual differences in uses of humor and their relation to psychological wellbeing: Development of the humor styles questionnaire. Journal of Research in Personality 37(1). 48-75.

Noonan, Will. 2011. Reflecting back, or What can the French tell the English about humour? Sydney Studies in English 37. http://openjournals.library.usyd.edu.au/index.php/SSE/ article/view/5321.

Partington, Alan. 2006. The Linguistics of Laughter. A corpus-assisted study of laughtertalk. London: Routledge.

Peeters, Bert (ed). 2006. Semantic Primes and Universal Grammar: Empirical evidence from the Romance languages. Amsterdam: John Benjamins.

Provine, R. R. 2000. Laughter: A scientific investigation. New York: Penguin.

Radcliffe-Brown, A. R. 1940. On joking relationships. Journal of the International African Institute 13(3). 195-210. http://www.jstor.org/stable/1156093.

Tran-Gervat, Yen-Mai. 2016. Humour studies in France: The situation and some perspectives. Seminar 24/08/16, AHSN and Dept of French Studies, University of Sydney.

Wierzbicka, Anna, 1972. Semantic primitives. Frankfurt am Main: Athenäum. 
Wierzbicka, Anna. 1996. Semantics: Primes and universals. New York: Oxford University Press. Wierzbicka, Anna. 1997. Understanding cultures through their key words. Oxford: Oxford University Press.

Wierzbicka, Anna. 1999. Emotions across languages and cultures. Cambridge: Cambridge University Press.

Wierzbicka, Anna. 2010. Experience, evidence, sense: The hidden cultural legacy of English. Oxford: Oxford University Press.

Wierzbicka, Anna. 2014a. Imprisoned in English: The hazards of English as a default language. New York: Oxford University Press.

Wierzbicka, Anna. 2014b. "Pain" and "suffering" in cross-linguistic perspective. International Journal of Language \& Culture 1(2). 149-173.

Ye, Zhengdao (ed). 2017. The semantics of nouns. Oxford: Oxford University Press.

\section{Bionotes}

\section{Cliff Goddard}

Cliff Goddard is Professor of Linguistics at Griffith University. He is a proponent of the Natural Semantic Metalanguage approach to semantics and its sister theory, the cultural scripts approach to pragmatics. His recent publications include "Words and Meanings: Lexical Semantícs Across Domains, Languages and Cultures" (co-authored with Anna Wierzbicka; OUP 2014), and the edited volumes "Happiness and Pain Across Languages and Cultures" (co-edited with Zhengdao Ye; Benjamins, 2016) and "Minimal English for a Global World: Improved Communication Using Fewer Words" (Palgrave, in press/2017). Email: c.goddard@griffith.edu.au.

\section{Kerry Mullan}

Kerry Mullan is Convenor of Languages and a member of the Social and Global Studies Centre at RMIT University. She teaches French language and culture, and sociolinguistics. Her main research interests are cross-cultural communication and differing interactional styles particularly those of French and Australian English speakers. She also researches in the areas of intercultural pragmatics, discourse analysis, language teaching and conversational humour. Email: kerry.mullan@rmit.edu.au. 